\title{
CONTROL OVER DISTRIBUTION OF CONSTRUCTION LOADS ON FOUNDATIONS OF TOWER BUILDINGS
}

\author{
Viktor Volkov \\ Saint Petersburg State University of Architecture and Civil Engineering \\ Vtoraja Krasnoarmejskaja ul. 4, St. Petersburg, 190005, Russia \\ tnvolkova@energaziz.ru
}

\begin{abstract}
The article describes the tasks and traditional approach to organization of full-scale instrumental observations over vertical deformations of engineering tower structures. Issues related to interpretation and use of the results of repeated geodetic observations during the study of tower structure foundation deformations are considered. The article presents an algorithm for processing of the results of repeated leveling of deformation control benchmarks set along the foundation perimeter, which allows calculating mutual displacement of settlement points due to local deformations of foundations, accompanying gradual settlement of foundation base groups. A possibility of identifying a direction of total foundation inclination is outlined for the purpose of effective management decisions related to adjustment of construction process with regard to redistribution of loads along the perimeter of tower structure foundation with the aim to eliminate its inclination.
\end{abstract}

\section{Keywords}

Tower structures, settlement, deformations of foundations, repeated geodetic observations, foundation inclination, redistribution of loads on foundation, elimination of foundation inclination

\section{Introduction}

Modern engineering tower structures, behavior of which depends on strict adherence to design solutions during construction and their stability during maintenance, include reactor buildings and cooling towers of nuclear power plants, blast furnaces, elevators, television towers, and other high-rise structures.

High-rise tower structures are characterized by load concentration reaching tens of thousands of tons and more (Mikhelev et al., 1977, Bolshakov et al., 1980) on foundations of small size (more often, base slabs). Heavy concentrated loads on foundations and their beds cause rapid and considerable settlement of high-rise structures under construction.

A distinctive feature of high-rise tower structures is their sensitivity to relatively inconsistent foundation inclinations due to non-uniform deformations (compaction) of foundation subgrades. Non-uniform deformations of subgrades occur often because of uneven construction loads on the foundation, even upon homogeneous structures and physical and mechanical properties (compressibility).

\section{Subject, tasks and methods}

Construction technology for tower structures provides for support of construction works with geodetic surveying to observe possible deformations of erected structures. Suffice to say that every single construction of tower structures is completed with repeated high-precision geodetic surveying revealing presence or absence of foundation settlements, i.e. passive control of foundation settlements and such generated deformations as inclinations is performed.

The practice of geodetic surveying of deformations of tower engineering structures (Bolshakov et al., 1980; Bright et al., 1959; Ganshin et al., 1981; Clough et al., 1979; Mikhelev et al., 1977; Volkov, 2015; Costachel, 1967; Mishra, 2011; Rincon, 2013) points out the necessity to monitor distribution of construction loads, transmitted from a part of the erected tower structure to the foundation and soils, with the help of repeated geodetic observations providing reliable designed condition of structures both during its construction and maintenance.

There is no method of distribution of construction loads during construction of tower engineering 
structures using results of repeated high-precision and accurate geodetic observations which include repeated leveling of deformation control benchmarks along the perimeter of foundation slabs of erected high-rise structures. Passive control of settlements of such deformation control benchmarks allows only calculation of inclinations in separate directions connecting two deformation control benchmarks, but does not allow establishment of total inclination of the foundation slab and its azimuth, which, in its turn, eliminates ability to control and modify construction loads, leading to inclinations of erected structures.

To solve these problems, a special technique of processing of the results of repeated leveling of deformation control benchmarks was developed; this technique allows control and distribution of loads across foundations of tower structures under construction with the help of identified total inclinations of foundations, occurring as a result of total gradual settlements, followed by development of an algorithm for their elimination.

\section{Results and discussions}

The essence of the proposed method is as follows. Non-uniform deformations of the structure foundations generate their inclinations which are characterized by indicators well-known in the engineering and geodetic practice, such as inclinations in the direction of longitudinal $i_{x}$ and transverse $i_{y}$ axes of the structure (Bolshakov et al, 1980; Kosterin, 1990; A. Filiatrault et al., 2013; Paz, 2012). In order to adjust the construction flowsheet, the proposed method allows for establishment of the maximum increasing amount of inclination of the structural foundation $i_{\max }$ and its direction (azimuth). To this end, deformation control benchmarks are marked along the perimeter of the foundation of the erected tower structure (Figure 1), which after a period of time $T$ are repeatedly leveled (leveling of Class I and II, 1982; Zharnikov et al., 1990). The first and subsequent cycles of repeated geodetic observations include laying of leveling lines from the reference benchmark to each deformation control benchmark $j=\overline{1, m}$. According to the results of the first cycle of leveling, exceedances between deformation control benchmarks and their levels $H_{1}, H_{2}, \ldots, H_{m}$ are determined.

By taking deformation control benchmarks $1,2, \ldots, m$ by turn as the origin of coordinates, the levels of remaining deformation control benchmarks are calculated on the basis of exceedances in two compared cycles. Comparing the levels of deformation control benchmarks received during two cycles, we receive the first row of discrepancies $\delta_{k j}$. Similarly, taking the $2^{\text {nd }}, 3^{\text {rd }}, \ldots, m$-th deformation control benchmark as the origin of coordinates, we get $m$ rows of discrepancies $\delta_{k j}(k=\overline{1, m}$ and $j=\overline{1, m}$ are the numbers of deformation control benchmarks, respectively, for which discrepancies between levels and values taken as the coordinates origin are calculated).

Thus, these rows of discrepancies are tabulated (Table 1), revealing a quadratic symmetric matrix $A_{m}$ with diagonal elements $\delta_{k j}=0$ symmetrically equal in absolute magnitude but opposite in sign to nondiagonal elements $\delta_{k j}=-\delta_{j k^{*}}$

$\delta_{a v . j}$ value is the value of average displacement of $j^{\text {th }}$ deformation control benchmark in relation to all deformation control benchmarks, occurred during a period of time $T$ between two cycles of repeated leveling.

Estimation of destabilization or invariance of the level of deformation control benchmarks during a period of time $T$ is carried out on the basis of analysis of values $S_{a v}=\frac{\left[\delta_{k j}\right]}{m-1}$. Benchmarks falling within the inequality $\left|S_{a v}\right| \leq t_{\beta} \mu \sqrt{\pi S_{a v . j}}$ (where $\mu$ is the mean square error of the unit weight, $\pi S_{a v . j}$ is a reverse weight of value $S_{a v . j}$, $t_{\beta}$ is a coefficient of conversion from mean square errors to limit errors) refer to deformation control benchmarks that have preserved their high-rise level (Volkov et al, 2015; Mikhelev et al., 1977). Otherwise, the deformation control benchmark belongs to the category of unstable values, i.e. benchmarks with considerable settlement.

Differences of significant average displacements $\delta_{j+1}-\delta_{j}, \delta_{j+2}-\delta_{j}, \ldots, \delta_{j+m}-\delta_{j}$ reveal reciprocal (local) displacement of deformation control benchmarks $j$ and $j+1, j$ and $j+2, \ldots, j$ and $j+m$ during a period of time $T$.

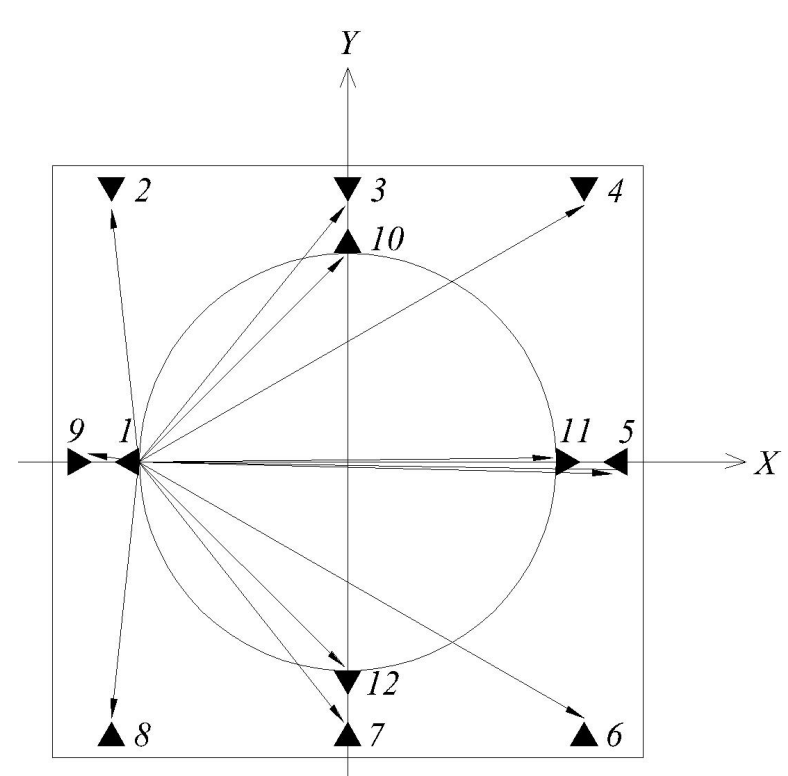

A deformation control benchmarks

Figure 1. Layout of deformation control benchmarks (through example of a foundation slab of a reactor building of a nuclear power plant) 
Table 1

Values of average displacement of deformation control benchmarks

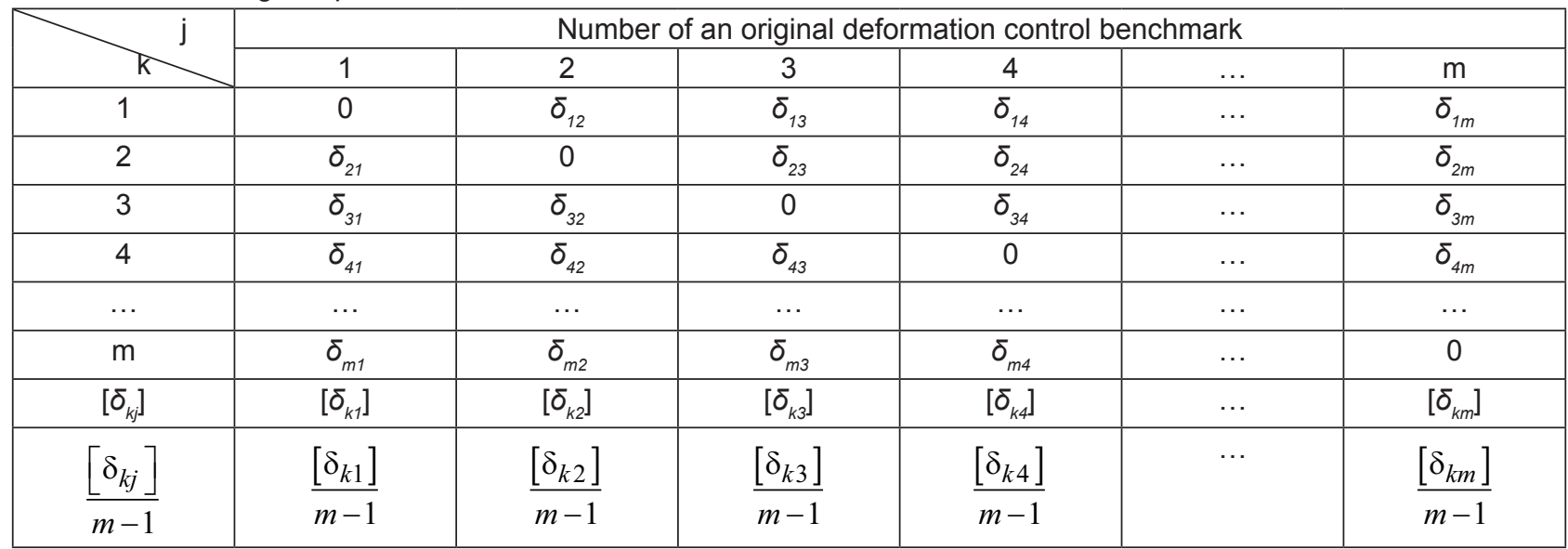

Taking one of the main axes of the tower structure (foundation), passing through one of the invariable deformation control benchmarks (reference), as an "original" point, we determine direction azimuth $A$, passing through the reference and other benchmarks (according to our example (Fig. 1) $-A_{1-2}, A_{1-3}, A_{1-4}$, $\left.\ldots, A_{1-12}\right)$. Separate inclinations $i_{1-2}, i_{1-3}, i_{1-4}, \ldots, i_{1-12}$ are defined according to selected directions 1-2, 1-3, $1-4, \ldots, 1-12$ :

$$
\begin{gathered}
i_{1-2}=\frac{\delta_{1}-\delta_{2}}{T \cdot S_{1-2}} \rho^{\prime \prime}, i_{1-3}=\frac{\delta_{1}-\delta_{3}}{T \cdot S_{1-3}} \rho^{\prime \prime}, \ldots, \\
i_{1-12}=\frac{\delta_{1}-\delta_{12}}{T \cdot S_{1-12}} \rho^{\prime \prime},
\end{gathered}
$$

where $S$ is the distance between the "original" and $j^{\text {th }}$ deformation control benchmarks, $\rho "=206265 "$.

Inclinations of the foundation (in our case, of the foundation slab) along the selected directions are represented with equations forming the following system:

$$
\begin{aligned}
& i_{1-2}= i_{x} \operatorname{Cos} A_{1-2}-i_{y} \operatorname{Sin} A_{1-2} \\
& \ldots \ldots \ldots \ldots \ldots \\
& i_{1-12}= i_{x} \operatorname{Cos} A_{1-12}-i_{y} \operatorname{Sin} A_{1-12},
\end{aligned}
$$

where $i_{x}$ and $i_{y}$ are separate inclinations along the selected directions, defined according to the system of equations (2) with the least-square method.

The value of the total inclination in a linear measure is calculated with the following formula (Volkov, Severgin, 1989):

$$
I=\sqrt{i_{x}^{2}+i_{y}^{2}} .
$$

The azimuth (grid azimuth) specifying the direction of the total inclination is calculated according to the formula (Volkov, Severgin, 1989):

$$
\operatorname{arctg} A_{t o t}=\frac{i_{y}}{i_{x}} .
$$

The further loading of the slab along the line with azimuth $A_{\text {tot }} \pm 180^{\circ}$ leads to decrease of inclination with regard to the foundation and the whole tower construction as a consequence.

\section{Conclusions}

The proposed method makes it possible to draw load diagrams for foundations of tower structures (reactor buildings of nuclear power plants, elevators, blast furnaces, etc.) according to repeated geodetic observations, taking into account uneven deformations of foundation soils during construction.

\section{References}

Bolshakov, V. et al. (1980). Spravochnoe rukovodstvo po inzhenerno-geodezicheskim rabotam [Reference guide for engineering and geodetic works]. Moscow: Nedra. (in Russian)

Bright, P. et al. (1959). Izmerenie osadok i deformacij sooruzhenij geodezicheskimi metodami [Measurement of settlements and deformations of structures using geodetic methods]. Moscow: Geodezizdat. (in Russian)

Chief Directorate of Geodesy and Cartography of the USSR Council of Ministers (1982). Nivelirovanie I i II klassov (prakticheskoe rukovodstvo) [Leveling of Classes I and II (practical guide)]. Moscow: Nedra. (in Russian)

Clough, R. et al. (1979). Dinamika sooruzhenij [Dynamics of structures]. Moscow: Stroyizdat. (in Russian)

Costachel, A. (1967). Einigeneue Aspectebei Prдzisionsnivellementszur Bestimmung der Senkung von Bauten. Vermessungstechnik, 7, pp. 250-257. (in German) 
Filiatrault, A. et al. (2013). Elements of Earthquake Engineering and Structural Dynamics. Paris: Presses inter Polytechnique.

Ganshin, V. et al. (1981). Izmerenie vertikal'nyh smeshhenij sooruzhenij i analiz ustojchivosti reperov [Measurement of vertical structural displacements and analysis of stability of reference benchmarks]. Moscow: Nedra. (in Russian)

Gersevanov Research Institute of Bases and Underground Structures of the Russian State Committee for Construction, Architectural and Housing Policy (1975). Rukovodstvo po nabljudenijam za deformacijami osnovanij i fundamentov zdanij i sooruzhenij [Guide on observations over deformations of foundations and bases of buildings and structures]. Moscow: Stroyizdat. (in Russian)

Kosterin, Ye. (1990). Osnovanija i fundamenty: Ucheb. posobie dlja vuzov [Foundations and bases: manual for graduate students]. Moscow: Vysshaya Shkola. (in Russian)

Mikhelev, D. et al. (1977). Geodezicheskie izmerenija pri izuchenii deformacij krupnyh inzhenernyh sooruzhenij [Geodetic measurements during studies of deformations of large engineering structures[. Moscow: Nedra. (in Russian)

Mishra, D.C. (2011). Gravity and Magnetic Methods for Geological Studies. Hyderabad: BS Publications.

Paz, M. (2012). Structural Dynamics: Theory and Computation. Berlin: Springer Science \& Business Media.

Rincon, L. (2013). Evaluation of the environmental impact of experimental buildings with different constructive systems using Material Flow Analysis and Life Cycle Assessment. Applied Energy, 109, pp. 544-552.

Volkov, V. (2015). Program- and Goal-Oriented Approach to Organization of Monitoring Deformations of Buildings and Structures. Applied Mechanics and Materials, 725-726, pp. 118-123.

Volkov, V. et al. (2015). Novyj podhod k matematicheskoj obrabotke rezul'tatov povtornyh geodezicheskih nabljudenij, ispol'zuemyh $v$ arhitekturno-stroitel'noj praktike [New approach to mathematical processing of the results of repeated geodetic surveys used in architecture and construction field]. Vestnik grazhdanskikh ingenerov [Bulletin of Civil Engineers], 6(53), pp. 216-221. (in Russian)

Volkov, V., Severgin, Ye. (1989). Issledovanie vlijanij vertikal'nyh dvizhenij zemnoj kory na ustojchivost' jenergeticheskih objektov [Study of effects of vertical crustal movements on stability of energy facilities]. Geodesy and Cartography, 2 , pp. 23-26. (in Russian)

Zharnikov, V. et al. (1990). O klassah geometricheskogo nivelirovanija dlja kontrolja deformacij [On classes of geometric leveling for control of deformations]. Geodesy and Cartography, 9, pp. 22-26. (in Russian) 